\title{
Entrepreneurial universities and entrepreneurship in education
}

\author{
Irina Pavlova ${ }^{1, \text { a }}$, Violetta Chernobuk ${ }^{2}$ \\ ${ }^{1}$ Tomsk Polytechnic University, 634050, Lenin Avenue, 30, Tomsk, Russia \\ ${ }^{2}$ Tomsk State University of Control Systems and Radioelectronics, 634050 Lenin Avenue, 40, Tomsk, Russia
}

\begin{abstract}
This research paper focuses on transformation of university educational processes with introduction of project-based learning to foster entrepreneurship in education. It addresses the educational process in universities in the context of academic entrepreneurship in different country-specific settings. In addition, it explains the factors influencing the development of entrepreneurial education environment exploiting entrepreneurial opportunities in a regional university in Russia. The authors use four case studies of entrepreneurial universities: Massachusetts Institute of Technologies (MIT), National Singapore University (NSU), Moscow Institute of Physics and Technology (MIPT) and Tomsk State University of Control Systems and Radioelectronics (TUSUR).
\end{abstract}

\section{Introduction}

In recent decades a university is perceived as one of the key mechanisms determining the competitive position of the countries as well as the level of economic growth and social development. It expands its functions through an understanding of the necessity to establish closer connections between the university activities and socioeconomic needs. This ongoing transformation has forged the concept of an entrepreneurial university.

This study is based on four different cases of two world-known and two Russian universities. The main objective of the study is to compare university entrepreneurship education models in different national settings (the USA, Singapore and Russia). The second objective is to determine the factors influencing entrepreneurial environment and entrepreneurship in education in a Russian regional university.

\section{Literature review and research methods}

Academic revolutions reshaped the modern university, which is understood today as under constant transformation. According to Etzkowitz and Webster, the second academic revolution created a possibility for universities to become centers for advanced science, thus, translating the research results into intellectual property, trade and economic development [1]. Slaughter and Leslie stress structural changes in science and identify them as "academic capitalism" [2]. Etzkowitz and Leydesdorff propose a non-linear triple helix "university-industry-government" model, in which

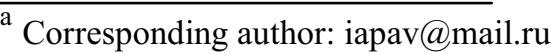

entrepreneurial universities are seen as the drivers of the knowledge-based economy [3, 4].

Nowadays, universities perform three functions educational, research and entrepreneurial [5]. The entrepreneurial function, the most recent for universities, is often associated with the third university mission. In the literature, there are three key aspects characterizing this function, or mission, which are social, entrepreneurial and innovation ones. B.Clark coined the term of an entrepreneurial university referring to the university's crucial activities among which he names strengthening the university core and its governance, enhancing interaction with external businesses and organizations, diversification of financial sources, fostering university entrepreneurial activities [6].

Entrepreneurship in education is an inherent feature of an entrepreneurial university. It can have immediate outcomes such as an enhanced employability, institutional enhanced reputation, a higher rate of startups creation, etc. At the same time, it leads to global impacts like enhanced social cohesion, sustainability, competitive economy, a higher level of innovation and, finally, economic growth [7]. Edward B. Roberts, the founder of the Center for Entrepreneurship in MIT, sees the reason of high population of the university and its successes depending on the reputation: "Students of MIT choose our university because they are sure that they will get all necessary skills and support to start business. It is the same for academics and other staff. Some authors call this a phenomenon of "a feedback loop". The more entrepreneurs MIT produces, the stronger the business environment around the university is and the better the reputation becomes, the more likely that students, academics and new partners come to MIT" [8]. 
As the main cases used for this study we explore 4 universities: Massachusetts Institute of Technologies (MIT), National Singapore University (NSU), Moscow Institute of Physics and Technology (MIPT) and Tomsk State University of Control Systems and Radioelectronics (TUSUR). The choice of universities for the analysis was based on the geographic location, the university's role in a particular country, relations with the world community, as well as a variety of approaches to the educational process. The main factor for choosing the universities was the fact that these institutions were originally established and were developing as universities primarily focusing on research. The innovative environment was formed around them in a natural way. Also, the first three universities are national leaders and also take leading positions in the world universities rankings [9-11] (Table 1).

Table 1. Universities in World Universities Rankings, 2015.

\begin{tabular}{|c|c|c|c|}
\hline & MIT & NUS & MIPT \\
\hline $\begin{array}{c}\text { Times Higher } \\
\text { Education } \\
\text { Ranking } \\
\text { (THE) }\end{array}$ & 5 & 26 & $601-800$ \\
\hline $\begin{array}{c}\text { QS World } \\
\text { University } \\
\text { Ranking (QS) }\end{array}$ & 1 & 12 & $431-440$ \\
\hline $\begin{array}{c}\text { Academic } \\
\text { Ranking of } \\
\text { World } \\
\text { Universities } \\
\text { (ARWU) }\end{array}$ & 3 & $101-150$ & $501-1200$ \\
\hline
\end{tabular}

For the study we take two internationally known universities and two Russian universities. For the Russian case we analyze a national-level (MIPT) and a regional-level (TUSUR) university. The findings are based on studying university management initiatives, motivation, knowledge flows, innovation infrastructure, business involvement, etc. The analysis builds upon literature study, statistical data, universities' selfassessment papers and reports, research of official university documents. In case of TUSUR, the authors also interviewed project leaders of 30 university projects to determine the factors influencing entrepreneurial environment and entrepreneurship in education in a Russian regional university.

\section{Research Findings}

Massachusetts Institute of Technologies (MIT) is one of the first universities that transformed their educational processes to achieve business objectives. Initially, the university focused its attention on physics and engineering disciplines, but then new educational trends became necessary to achieve the effect of an interdisciplinary approach. At the initiative of Sloan School of Management a financial center was established which made it possible to develop interdisciplinary projects.
Most of the educational programs in MIT are based on a short lecture course and are more associated with the practical activity that takes place under the supervision of existing businesses. In addition, MIT has been developing its own educational programs to improve entrepreneurial skills for over two last decades. Table 2 provides with the summary of the key indicators of entrepreneurial activities in the educational processes in MIT [12].

Table 2. Key indicators of entrepreneurial activities in the educational processes in MIT.

\begin{tabular}{|c|c|}
\hline MrT & MIT \\
\hline $\begin{array}{c}\text { Wide variety of } \\
\text { educational } \\
\text { programs }\end{array}$ & $\begin{array}{c}\text { Programs provide with an opportunity } \\
\text { attracting undergraduate students in } \\
\text { research projects. }\end{array}$ \\
\hline $\begin{array}{c}\text { Interdisciplinary } \\
\text { approaches }\end{array}$ & $\begin{array}{c}\text { A great variety of interdisciplinary } \\
\text { projects that were initiated by students } \\
\text { from different schools and departments. }\end{array}$ \\
\hline $\begin{array}{c}\text { Business } \\
\text { participation in } \\
\text { the educational } \\
\text { process }\end{array}$ & $\begin{array}{c}\text { Most educational courses are taught by } \\
\text { acting entrepreneurs. }\end{array}$ \\
\hline $\begin{array}{c}\text { Involvement of } \\
\text { students in the } \\
\text { work at a } \\
\text { company }\end{array}$ & $\begin{array}{c}\text { Students do research in collaboration } \\
\text { with leading regional companies. }\end{array}$ \\
\hline $\begin{array}{c}\text { Key } \\
\text { characteristic }\end{array}$ & $\begin{array}{c}\text { Development of educational programs } \\
\text { aimed at obtaining business skills, } \\
\text { involvement of experts from the } \\
\text { company as mentors. }\end{array}$ \\
\hline
\end{tabular}

The National University of Singapore (NUS) is one of a few leading universities located in Asia which has its own unique educational approaches that are implemented in order to increase the entrepreneurial activity in the university. NUS' educational programs include a variety of activities such as the exchange of students, internships at enterprises, and they offer the possibility to obtain a double degree diploma. The development strategy of NUS highlights 4 main priority areas [13]:

- a practice-oriented educational process;

-NUS uses a project-based learning model and implements funding of student ideas (Extra Chapter Challenge, and Innovation \& Entrepreneurship Practicum Seed Grant);

-business development consulting services and accelerator programs, as well as creating platforms for startups interaction (Start-up @ Singapore, Techno-Venture Forums, Social Business Week);

-development of infrastructure;

-development of research activities.

One of the priorities of the National University of Singapore is to encourage interdepartmental cooperation for students, academics and university staff. Students are free to study subjects that they want for the first two terms. An essential stage of finishing the study at NUS for both undergraduate and graduate students is working 
in projects that are implemented within a specific existing business or in cooperation with the government. Table 3 provides the summary of the key indicators of entrepreneurial activities in the educational processes in NUS [14].

Table 3. Key indicators of entrepreneurial activities in the educational processes in NUS.

\begin{tabular}{|c|c|}
\hline Project study & $\begin{array}{c}\text { Nus } \\
\text { Project study is an integral part for } \\
\text { graduation. }\end{array}$ \\
\hline $\begin{array}{c}\text { A wide variety } \\
\text { of educational } \\
\text { programs }\end{array}$ & $\begin{array}{c}\text { Students may choose studying discipline } \\
\text { by themselves for the first two terms, } \\
\text { even if they want to visit classes of } \\
\text { other departments. Students also have } \\
\text { the opportunity to be taught under the } \\
\text { program of double diplomas (Bachelor } \\
\text { of Engineering and Business, Bachelor } \\
\text { of Business and Law). }\end{array}$ \\
\hline $\begin{array}{c}\text { Interdisciplinary } \\
\text { approaches }\end{array}$ & $\begin{array}{c}\text { The main focus is on building } \\
\text { communication between departments } \\
\text { and faculties, engaging students in } \\
\text { different aspects of a single project. }\end{array}$ \\
\hline $\begin{array}{c}\text { Business } \\
\text { participation in } \\
\text { the educational } \\
\text { process }\end{array}$ & $\begin{array}{c}\text { Participation of large state-owned } \\
\text { corporations in educational projects. }\end{array}$ \\
\hline $\begin{array}{c}\text { Involvement of } \\
\text { students in the } \\
\text { work at the } \\
\text { company }\end{array}$ & $\begin{array}{c}\text { The cooperation of the University with } \\
\text { the major national companies: } \\
\text { HP/Compaq, GE, Philips, Siemens, } \\
\text { Matsushita/Panasonic, Microsoft, } \\
\text { Toshiba, Seagate. }\end{array}$ \\
\hline $\begin{array}{c}\text { Key } \\
\text { characteristic }\end{array}$ & $\begin{array}{c}\text { Focus on project study and case study } \\
\text { models. }\end{array}$ \\
\hline
\end{tabular}

Moscow Institute of Physics and Technology (MIPT) is one of the best examples of building an entrepreneurial university ecosystem in Russia. Currently, MIPT combines fundamental research with early involvement of university students in applied science. Most of the academic departments are based on extremely close cooperation with the institutes, the Russian Academy of Sciences (RAS) and high-tech enterprises. Since the 1990s, MIPT has changed its development plan from "pure science" to the generation of high-tech business within the university walls and has become one of the first universities in Russia leading the creation of an entrepreneurial university [15].

The MIPT educational system is an experimental basis where effective new technology trainings of elite scientific and engineering staff have been practiced for more than 60 years. It consists of the following:

- the system of applicants selection;

- a high level of training in technical areas with the leading scientists of the country;

- early students involvement in R\&D activities in cooperation with leading institutes of the RAS and large high-tech companies, etc.

The high integration of business into MIPT environment can be detected back to the stage of enrollment of applicants. The selection of the future students is significantly different from other Russian universities. The second stage of the exam, which is organized in the form of an interview, takes place with a board of 20-30 scientists and academics including not only the teachers and professors of the university, but also representatives of businesses that cooperate with the university actively. Thus, the decision mostly depends on the opinion of the board members [16].

Key majors in MIPT fully correspond to the top priority development areas of science, technology and engineering in Russia. In total, the university has about 4,000 students, and only full-time education is available in MIPT. The university is famous for its academic staff because $2 / 3$ are members of the research organizations who combine their work in MIPT with the work in other organizations. $70 \%$ of full-time academics hold $\mathrm{PhD}$ degrees. Moreover, the educational process involves more than 80 members of the Russian Academy of Sciences.

Nowadays, the strategy of the university is that a student combines three out of six years of study with the work in research and industrial organizations. Currently, there are more than 100 MIPT basic departments in Moscow and Moscow region. And along with the traditional department, the world's largest high-tech companies (1C, Intel, ABBYY, IBS, Parallels, Cognitive Technologies, Rostelecom, RVC, RUSNANO, Yandex, Rosneft, Schlumberger) launch their own departments, which participate in the educational process of the university and provide student with workplaces for professional training and internships. It is worth mentioning that all practice-oriented training activity within enterprises in MIPT is an essential part of studies. MIPT founded several interfaculty departments, which allow overcoming interdepartmental cooperation obstacles. One example is the department of RUSNANO Company. Students gain theoretical knowledge in one of the basic department. Practical competence is acquired by participating in the various projects carried out by organizations under contracts with the company [17]. Table 4 provides the summary of the key indicators of entrepreneurial activities in the educational processes in MIPT [17-18].

Table 4. Key indicators of entrepreneurial activities in the educational processes of MIPT.

\begin{tabular}{|c|c|}
\hline & MIPT \\
\hline Project study & $\begin{array}{l}\text { The project study is an essential } \\
\text { component of an entrepreneurial process } \\
\text { and is operationalized within the } \\
\text { scientific departments and in companies. }\end{array}$ \\
\hline $\begin{array}{l}\text { A wide variety } \\
\text { of educational } \\
\text { programs }\end{array}$ & $\begin{array}{l}\text { Programs provide with an opportunity } \\
\text { of getting double diplomas but students } \\
\text { cannot build their individual educational } \\
\text { process. }\end{array}$ \\
\hline $\begin{array}{l}\text { Interdisciplinary } \\
\text { approaches }\end{array}$ & $\begin{array}{c}\text { Creation of interdisciplinary } \\
\text { departments. }\end{array}$ \\
\hline $\begin{array}{l}\text { Business } \\
\text { participation in } \\
\text { the educational } \\
\text { process }\end{array}$ & $\begin{array}{l}\text { Launching departments together with } \\
\text { the companies such as 1C, Intel, } \\
\text { ABBYY, IBS, Parallels, Cognitive } \\
\text { Technologies, Rostelecom, Rusnano, }\end{array}$ \\
\hline
\end{tabular}




\begin{tabular}{|c|c|}
\hline & Yandex, Schlumberger. \\
\hline $\begin{array}{c}\text { Involvement of } \\
\text { students in the } \\
\text { work of the } \\
\text { company }\end{array}$ & $\begin{array}{c}\text { Practical activities of the enterprises } \\
\text { represent an essential part of studying. } \\
\text { Three years out of six years of study } \\
\text { student spends in the scientific and } \\
\text { industrial organizations. }\end{array}$ \\
\hline $\begin{array}{c}\text { Key } \\
\text { characteristic }\end{array}$ & Bonds with enterprises. \\
\hline
\end{tabular}

On the basis of the mentioned-above approaches to the development of entrepreneurial skills, it is possible to identify key issues that are extremely relevant for entrepreneurial universities in the educational process: (1) project-based studies; (2) interdisciplinary approaches; (3) active cooperation with companies; (4) participation of business mentors in the educational process.

Being a regional university located in Siberia, Tomsk State University of Control Systems and Radioelectronics (TUSUR) launched the practiceoriented student training program in 2006. The GPBS program (group project-based studies) was supposed to form the necessary level of competence for future employment and engage students in research in order to obtain practical experience in the project teams and provide them with all necessary resources to set spin-off ventures.

Projects are initiated by the companies' employees or the departments of TUSUR. Some of them are based on the university research projects, but some of them are based on business needs of the companies, which closely cooperate with TUSUR. This business-oriented approach allows students to work with the companies to accomplish their GPBS educational and research tasks. GPBS takes one day a week in the students' schedule. Students are also motivated by extra monthly allowance for participation in GPBS projects.

The organizational structure of GPBS is clearly hierarchical. There is a separate corresponding official in charge of a separate stage of the process. Right before the start of a semester, each department holds an evaluation project selection session according to its research objectives. The projects are either one semester long or ongoing continuing projects for several semesters. Each semester the university numbers 280320 GPBS projects. The whole process is managed by the departments' vice heads of the GPBS projects who are fully responsible for the entire organizational process. All reports on the results of the project studies are transferred to the Center of Innovative Educational Technologies (CIET) and its members, who monitor the process of group project-based learning at the university level, transfer the data to the Office of Education of the university.

\section{Discussion and Conclusion}

Nowadays, Russian universities are highly motivated by international project-based entrepreneurship educational experience and try to reproduce this model. Henry
Etzkowitz stresses that any team or group work in a college or a university can finally lead to a business team or a company creation [19].

According to the GPBS results study in TUSUR, there are two basic approaches to project-based education identified. The first one is a traditional university research-oriented approach. Sometimes, such projects excessively focus on educational tasks. In addition, there is a clear evidence that companies, which cooperate with TUSUR, also take part in the projectbased education. Such a partner company can either generate a research idea or provide the university with finances, qualified personnel and material resources. These GPBS university projects of the second type can contribute to a greater business companies' research objectives. Therefore, it is necessary to differentiate the projects which are originated in accordance either with university or business interests.

After interviews with the heads of the GPBS projects, we were capable to formulate key factors that influence the overall GPBS process performance in TUSUR.

1. Time for the GPBS studies is strictly limited by 6 academic hours a week. Most heads of the projects see this situation as a problem, because of the fact that students often need more time for consulting with mentors. Besides, sometimes the access to the laboratory is regulated by the schedule.

2. Students often do not have enough knowledge and skills to accomplish tasks and much time is spent on acquisition of basic knowledge, considering the fact that students are mostly attached to the projects of the department where they study.

3. The monthly allowance (scholarship) is used as the main motivation to join the GPBS, but its sum is fixed. Most of the heads of the projects believes that this allowance, distributed by the university, as the primary motivator of entry into the project, plays both a positive and negative role. Some of the students join the project only because of the financial stimulus with no research or entrepreneurial interest.

4. There are projects that do not have any research or commercial application.

5. There is lack of funding to upgrade laboratory equipment, lab instruments and tools, etc. However, some projects raise extra funding through grants or partner companies.

6. The study also identified that projects do not use the opportunities of university innovative infrastructure. The most popular element of the innovative infrastructure is the business incubator. The vast majority of project teams either do not use the opportunities provided by the business incubator or use only offices and equipment facilities. None of the projects use consulting services.

7. Lack of interdisciplinary projects results is accompanied by the lack of people with specific professional knowledge. As research shows several projects in the engineering area need people who can work on marketing and legal problems.

Currently, the project-based form of studying plays an important role in entrepreneurial universities as a part of educational process. TUSUR is a good example of 
implementing this model in its educational process as a regional university. The key advantage of the GPBS is that it provides several alternative options for students who can continue their work in a company or in a university.

In the future, this research methods and findings will be spread on other Tomsk universities to compare entrepreneurship functioning in the educational process of different universities within the regional innovation system of Tomsk Oblast.

\section{Acknowledgment}

This research was performed in collaboration with Tomsk Polytechnic University with financial support of the Russian Foundation for the Humanities, research project No. 15-12-70002 "Institutions for regional economic development: formation processes".

\section{References}

1. H. Etzkowitz, A. Webster, Capitalizing knowledge. New intersections of industry and academia (Albany: State University of New York Press, 1998)

2. S. Slaughter, L. LeslieL, Academic capitalism: Politics, policies, and the entrepreneurial university. (Baltimore and London: Johns Hopkins University Press, 1997)

3. H. Etzkowitz, L. Leydesdorff, Minerva, 36, 203-208 (1998)

4. H. Etzkowitz, L. Leydesdorff, Research Policy, 29, 109-123 (2000)

5. I.A. Pavlova, E.A. Monastyrny, Innovatsii, 3, 39-44 (2015)

6. B.R. Clark, Creating Entrepreneurial Universities: Organizational Pathways of Transformation (Issues in Higher Education) (Emerald Group Publishing Limited, 1998)

7. A road to success. A compilation of evidence on the impact of entrepreneurship education strategies and measures. Directorate-General for Internal Market, Industry, Entrepreneurship and SMEs. European Commission. Luxembourg: Publications Office of the European Union, DOI: 10.2769/408497 (2015)

8. M. Trust, Entrepreneurial Impact: the role of MIT. Center for MIT Entrepreneurship. URL: http://entrepreneurship.mit.edu/impact/impact.html (accessed: 03.11.2015)

9. QS World University Rankings. Official Site. URL: http://www.topuniversities.com (accessed: 12.11.2015)

10. THE World University Rankings. Official Site. URL: $\quad$ https://www.timeshighereducation.co.uk (accessed: 12.05.2015)

11. ARWU World University Rankings. Official Site.URL: $\quad$ http://www.shanghairanking.com/ru/ (accessed: 12.05.2015)

12. E.B. Roberts, C.Eesley, Entrepreneurial Impact: the role of MIT (MIT Sloan School of Management, 2009)
13. S.K. Lee, C.B. Goh, B. Fredriksen, J.P. Tan, Towards a better future: education and training for economic development in Singapore since 1965. (Singapore: National University of Singapore, Washington D.C.: The World Bank, 2008)

14. A. Sudhendranath, The role of NUS in the startup ecosystem of Singapore. Official web-site Yourstory. URL: http://yourstory.com/2013/06/therole-of-nus-in-the-startup-ecosystem-of-singaporewith-director-of-nec-prof-wong-poh-kam/ (accessed: 29.10.2015)

15. MIPT Road Map. Official document. URL: https://mipt.ru/science/5top100/plan (accessed: 5.11.2015) (2014)

16. A. Staridubova, Scientific online-journal «Discussion», 4 (34), (2013)

17. MIPT self-assessment report. (MIPT, Moscow, 2014)

18. D. Medovnikov, V. Saraev, Innovative System of MIPT. Online journal "Expert". URL: http://expert.ru/expert/2013/44/innovatsionnayasistema-fizteha/ (2012)

19. H. Etzkowitz. The Triple Helix: University-IndustryGovernment Innovation In Action. (London: Routledge, 2008) 